\title{
Migration as an Adaptation Strategy to Climate Change: Influencing Factors in North-western Ghana
}

\author{
Nicholas Fielmua ${ }^{1}$, Dugle Gordon ${ }^{1} \&$ Darius T. Mwingyine ${ }^{1}$ \\ ${ }^{1}$ University for Development Studies, Wa, Ghana \\ Correspondence: Nicholas Fielmua, University for Development Studies, P.O. Box UPW 11, Wa, UWR, Ghana. \\ Tel: 233-2-4325-5001. E-mail: nfielmua@hotmail.com
}

Received: September 20, 2017

Accepted: October 5, 2017 Online Published: November 29, 2017

doi:10.5539/jsd.v10n6p155

URL: https://doi.org/10.5539/jsd.v10n6p155

\begin{abstract}
Climate change has attracted the attention of all stakeholders, ranging from individuals in the household through to global organisations in the international community. As an inevitable phenomenon at the moment, adaptation is the key response to minimising the unfavourable effects of climate change. While there are several adaptation strategies, rural areas mostly use migration as an ultimate and most reliable option. Rural migration in Ghana is mostly from the north to the south. This paper examines the factors that influence individuals and households' decision to use migration as an adaptation strategy to climate change effects in North-western Ghana. Data was collected using household questionnaire in four communities and analysed using statistical package for social science, version 20.0. The study established that although there are other reasons for migration, it is used essentially as an adaptation strategy to the effects of climate change on livelihood. The study concludes that the debate on climate change and migration should no longer be whether climate change causes human migration but how the effects of climate change influence migrants' resolve to migrate as an adaptation strategy. Such an analysis allows policy makers to find practical adaptive capacity measures that can offset the challenges at the original homes of migrants.
\end{abstract}

Keywords: migration, climate change, adaptation, migration decision factors, north-western Ghana

\section{Introduction}

Climate change and its ramifications are now commonly known from the household level through to the international community. Prominent among its evidence is the global rising temperatures (Lilleør \& Van den Broeck, 2011). In spite of suggestions that the world risks facing about $2^{\circ} \mathrm{C}$ increase in warming, the focus needs to go beyond impact and vulnerability to address issues of adaptation (Wise et al., 2014). Recent reports of the magnitude of climate change present adaptation as a key instrument in reducing its economic and social costs (Wise et al., 2014). The adaptation strategies are varied and include livelihood diversification, changes in timing and patterns of cropping, migration, irrigation rather than reliance on rain-fed agriculture, reforestation and soil reclamation (Deressa et al., 2009). Migration as a strategy was keenly noted by the Intergovernmental Panel on Climate Change (IPCC) in 1990 as the greatest single impact of climate change (Brown, 2008). Other scholars have established climate change as a push factor of migration (see, for example, Jones \& Boyd, 2011; Van Der Geest, 2004, 2011).

Notwithstanding the influence of climate change, migration has been a human practice for over centuries and as such is not new. Historically, several reasons have been given for migration, including social, economic, ecological/environmental, political, disasters, and security/wars (see, for example, Barnett \& Webber, 2010; Lilleør \& Van den Broeck, 2011; Morton et al., 2008; Van Der Geest, 2011). However, what has attracted the attention of the policy community and researchers in recent times is the unparalleled dimension of migration. With the insurgence of climate change discourse, human mobility has been stressed as a key adaptation strategy for those who are directly affected by climate change (Van Der Geest, 2004). While climate change is a global phenomenon, sub-Saharan Africa is most vulnerable to its effects (Conway \& Schipper, 2011). It is severe in rural areas, where livelihood largely depends on rain-fed agriculture and natural resources (Van Der Geest, 2011). It is estimated that populations displaced as a result of climate change will increase in the next two decades if the current greenhouse emission with its consequences on food and water resources is not changed (see McLeman, 2011). Developing countries are the most affected in terms of climate change induced migration. For example, in 
the remote areas of Botswana, drought was identified as the major challenge for the people (Maru et al., 2014), compelling them to seasonally migrate, as an adaptation strategy.

\section{Migration in Ghana}

In Ghana, migration is mostly from north to south (see Figure 1 on migration direction). The north-south migration in Ghana is related to the spatial distribution of natural resources where southern Ghana is naturally more endowed than the north. Also, colonial labour policies such as the recruitment of labour from the northern territories to work in the south have contributed to this pattern of migration. (Kwankye et al., 2009; Rademacher-Schulz \& Mahama, 2012). It is estimated that one out of every five people born in northern Ghana is living or has lived in southern Ghana (Van Der Geest, 2011). The major reasons for migration, especially the non-skilled migrants, are linked to: poor agro-ecological conditions in the north; parents' inability to take care of children, especially the young ones; desire of migrants to be independent in order to control their affairs without family interference; and socio-cultural factors, where young females migrate to acquire materials such as utensils and cloths to prepare for marriage (Kwankye et al., 2009; Van Der Geest, 2011). It is also established that returned migrants who bring items such as cloths, utilities and bicycles have been a source of motivation for younger people to also migrate in order to acquire similar items (Kwankye et al., 2009). These reasons are linked to the inability of households to adapt to the effects of climate change at the origin.

It has been argued that adaptation is a local practice, yet little is known about how local level actors (the immediate bearers of climate change effect) understand and frame the adaptation (Brugger \& Crimmins, 2013). While knowledge about how local people frame and conceptualise adaptation to climate change may actually be limited, it is evident that the locals are devising strategies to adapt to it. One of such strategies is migration and it remains central in the range of adaptation strategies in rural areas.

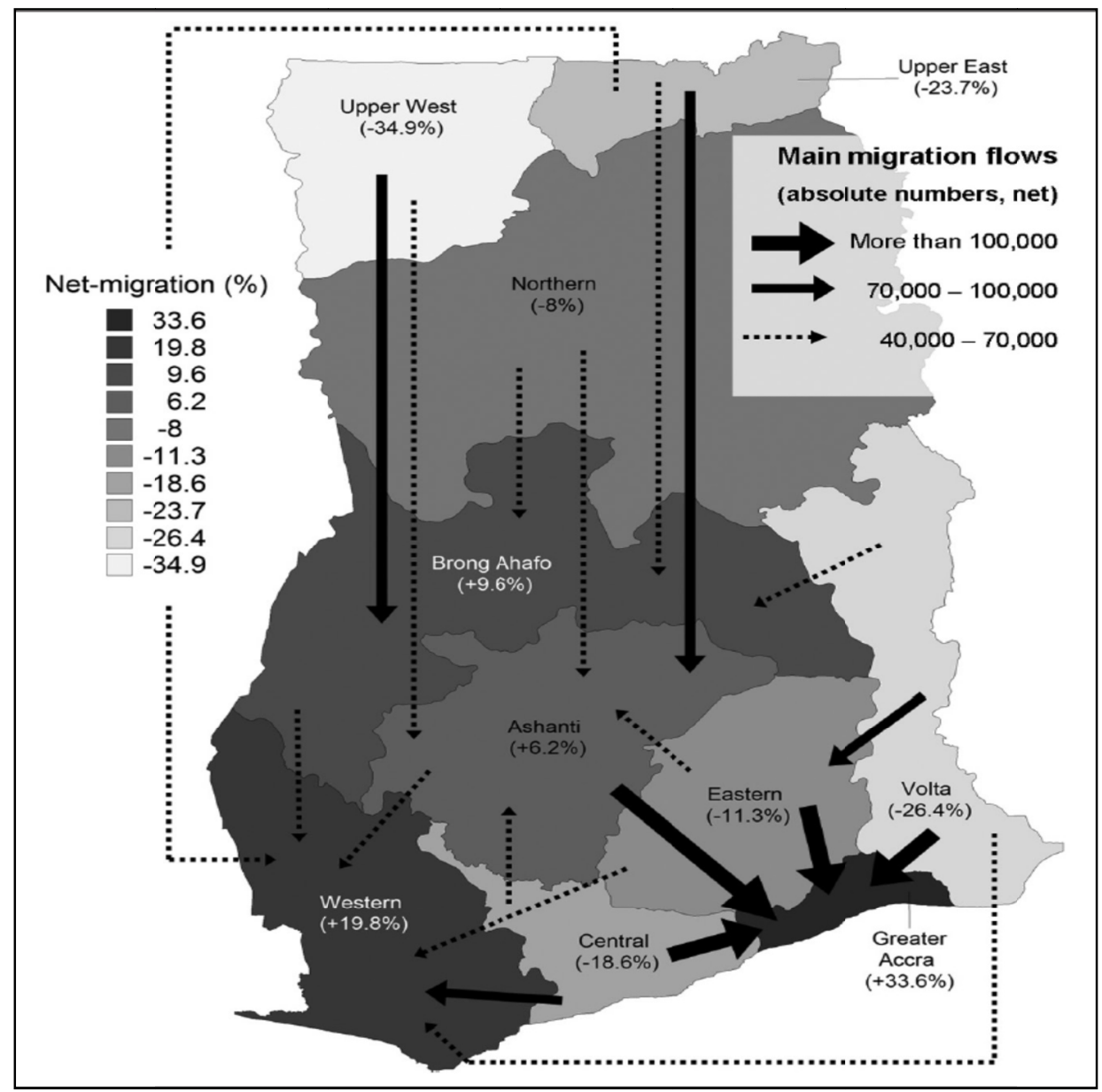

Figure 1. Direction of migration in Ghana

Source: Van Der Geest (2011). 
As shown in Figure 1, there is generally high migration from northern to southern Ghana but this paper focuses on migration from the Upper West Region of Ghana, specifically in the Nadowli-Kaleo district because migration is relatively high in this area, as demonstrated by the thickness of the arrow. Using data from the 2010 population and housing census in Ghana, Van Der Geest (2011) established that the highest migration propensities were found in north-western Ghana (including Nadowli-Kaleo District), where out-migration ranged from $40 \%$ to $60 \%$. Concurrently, annual rainfall decreased as one move towards the north, thus giving a negative relationship ( $\mathrm{R}=-0.713$, significance 0.000 ) between out-migration and precipitation (Van Der Geest, 2011:76). It was also established that in rural areas where livelihood depends on rain fed agriculture, climate change is likely to increase the rate of migration, especially rural-urban migration (McLeman \& Hunter, 2010).

Given that studies (see, for instance, Van Der Geest, 2004) have recognized migration as one of the consequences of climate change, it is of obvious interest to find out the rationale for this. This study sought therefore to find out why migrants from the North-western part of Ghana mainly use migration as an adaption strategy to climate change rather than other strategies. Specifically, the study sought to examine the factors that influence individuals and households' decision to use migration as an adaptation strategy to climate change in a migration stricken area, the Nadowli-Kaleo District of north-western Ghana.

\section{Theoretical Framework on Climate Change Adaptation and Migration}

In retrospect, just as migration is as old as the history of humanity, Van Der Geest (2004) indicated that climate change is an old-age phenomenon, and for that matter its associated effects of drought and famine. For example, in the present Sahara, the climate changed (between 2500 B.C. and 2300 B.C) from arable to a condition that only supported livestock (Van Der Geest, 2004). The change in land use equally suggests that adaptation is as old as climate change and for that matter, the human race but became an issue of concern much later. Brugger and Crimmins (2013) estimated the period of prominence of adaptation to be in the 1980s and 1990s. This awareness came with the establishment of international institutions such as the United Nations Framework Convention on Climate Change (UNFCCC) and the Inter-governmental Panel on Climate change (IPCC). Since its inception in 1988, the IPCC has been providing governments with scientific information on the causes of climate change, its impact on the various facets of lives, future risks and the potential options for adapting and mitigating climate change.

Migration and climate change have attracted the attention of many researchers and various dimensions of the two concepts have been framed. Hunter (2005) examined forced and voluntary migration in relation to climate change and confirmed that migration, as noted by Hugo (1996), is a continuum, ranging from voluntary migration through to totally forced migration. Within this continuum, very few migrations are at the extreme. Hugo's scale of migration can be mapped with what Gemenne and Dun described as slow-onset and sudden-onset of environmentally caused migration (see Van Der Geest, 2011). While sudden climate change events such as flood will forcibly move people, voluntarism relates to gradual or slow onset of climate change (Laczko \& Aghazarm, 2009).

In this paper, we argue that there is no evidence that a slow onset of climate change which 'perceivably' makes people to migrate is voluntary. That is, in the absence of such an onset of climate change, the people would not migrate. Hence, voluntary migration, especially in relation to climate change, remains contentious. Secondly, even when people migrate in anticipation of an event, such as climate change (McLeman, 2011), there are a set of interwoven drivers ranging from socio-economic to political that are implicit and in most cases confined to the mover (migrant). Therefore, it is argued here that even when the migrant indicates that the movement was based on voluntary ground, there are embedded factors (push or pull) that initiate the movement, without which there will not be movement. Our argument is supported by the fact that migration is expensive and the most affected are the rural poor, as also observed by Black et al. (2011).

Besides environmental or climate change argument on migration, from a welfare perspective, the neo-classical economics theorists' stance on migration falls within this continuum but shifted towards voluntary migration. It has been established that households and individuals take a decision to migrate after an assessment of the potential gains (economic gains in particular) that come with migration in relation to the costs associated with it (Hugo, 1996). This holds when the migrant has the liberty and luxury to assess and take a decision based on the costs and benefits associated with migration. In the case of forced migration, rationality is relegated to the background. For example, Van Der Geest (2011) found that during the colonial rule, forced migration was the tool used to get labour for mines and rail construction in southern Ghana. But voluntary migration started after the forced migrants returned to northern Ghana.

Mortreux and Barnett (2009), however, established that in Funafuti Island, Tuvalu, climate change is not a driver 
of migration or intention to migrate. Despite the challenges in the area, the social attachment that people have about Tuvalu motivates them to stay instead of migrating. Social drivers can also take the form of relationship with people who have already migrated and their attachment with their relations at the origins. For example, a study in Vietnam showed that remittance from out-migrants played an important role in building the adaptive capacity of the communities of origin (Adger et al., 2002). In such situations, two things emerge: (i) remitted beneficiaries are not likely to migrate as long as they receive remittance, and in most cases, the beneficiaries are the aged; and (ii) households (neighbours) that have no out-migrants, but motivated by the remittance of their neighbours, may encourage household members to migrate. This will depend on their household demographic characteristics such as age, marital status and educational level. Climate change can present opportunities for some households. For instance, at the international level, migration reduces poverty (in the country of origin) through remittance, from those who migrate to the developed world (Todaro \& Smith, 2009). Besides, even unskilled labour, for example, in Burkina Faso, who migrate to neighbouring Cote D'Ivoire to work in cocoa farms, have proved beneficial (Todaro \& Smith, 2009) to their people back home.

\subsection{Characterisation of Factors Linked to Climate Change}

There is a forward and backward link between climate change on the one hand, and socio-economic and environmental factors on the other. That is, while economic, social and environmental actions of individuals cause climate change, climate change in turn affect the social, economic and environmental fibre of society. The socio-economic and environmental factors that cause climate change and are affected by climate change will continue to change with time but how they influence people's decision to migrate remain constant (Black et al., 2011). Nonetheless, the focus is often on how climate change impacts on the society, economy and environment of individuals. Availability of employment opportunities at the origin and destination, current income from production activities are all economic related (Ishtiaque \& Ullah, 2013). Figure 2 conceptualises this linkage and further shows the foundation for decision making regarding using migration as an adaptation strategy.

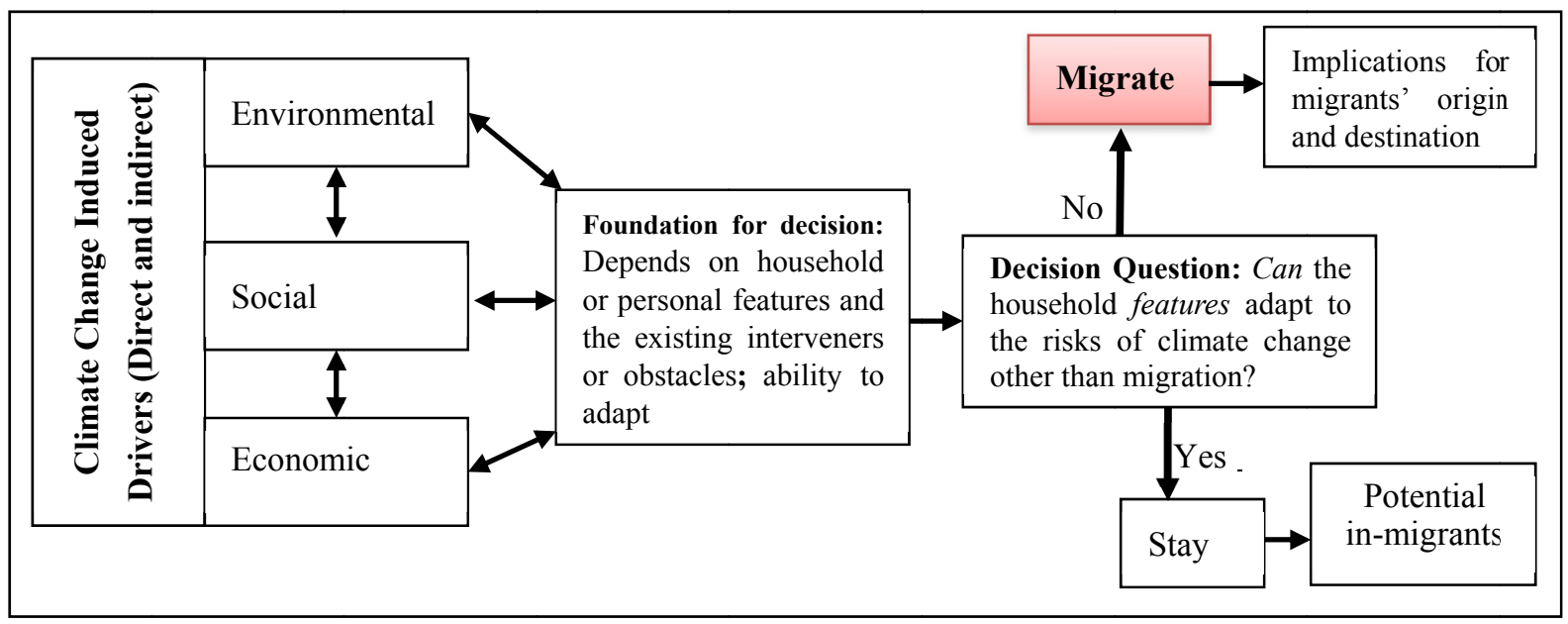

Figure 2. Migration as a strategy to minimise climate change effects

Source: Authors' construct based on Black et al. (2011).

There is a link between the three drivers; environmental, social and economic (see Figure 2). Renaud et al. (2011) explained that environmental drivers are in most cases, the consequences of degradation in the economic and social conditions and vice versa. With the impact of climate change on social, economic and environmental sectors, human migration become compulsory because these changes make some parts of the world less viable places to live (Brown, 2008).

Generally, climate change poses a variety of challenges including increased temperature, increased likelihood and severity of natural disasters, crop and livestock losses, more frequent and severe forest fires, and impacts on hydroelectric power generation and water-dependent ecosystems (see Kahn, 2003). The increase in extreme weather events such as heavy precipitation results in floods in many regions while rising temperature leads to drought (Lilleør \& Van den Broeck, 2011). Many other authors have established convincing links between climate change, natural effects and migration. For instance, Meier et al. (2007) have noted that droughts in the 
1970s and 1980s caused the migration of Malian Tuaregs to other countries. The 2004 tsunami in Indonesia displaced 500,000 people just as Hurricane Katrina in 2005 increased male migration from Honduras to Nicaragua (Smith, 2007).

Climate change has socio-economic effects. In terms of the economic side effects of climate change, studies (Gregory et al., 2005) have explored the links between climate change and food security, largely in relation to impacts on food production. These studies have identified that climate change endangers world food security. For instance, Gregory et al. (2005) identified that climate change may affect food systems in several ways ranging from direct effects on crop production, to changes in markets, food prices and supply chain infrastructure. Climate change has direct and indirect impacts on social issues including health and displacement of population. It affects the health of population in several ways. Additionally, in an attempt to reduce dependency on rain fed agriculture and green house emission, huge dams are constructed and the process of construction results in displaced population (Sherbinin et al., 2010). Despite the impact of climate change on the various facets of society, there are still factors that shape a household or individual decision to migrate.

\subsection{Decisive Factors in Migration}

Decision to migrate because of climate change is influenced by perceived or real better socio-economic conditions and opportunities at the destinations, level of deprivation at the origin, personal difficulties, existence of social networks at the destination, human values and the existing informal institutions (Parkins, 2010), as shown in Figure 2. Therefore, the perception of the risks ${ }^{1}$ of staying and the risks of migrating are important variables in one's decision to migrate (Barnett \& Webber, 2010) (see Figure 2 above). Many factors besides what is enumerated above could account for these considerations. In Ghana, Van Der Geest (2011) has found that family conflict, witchcraft, lack of non-farm income opportunities and the desire to be free and independent account for migration. In Zimbabwe, political factors and economic conditions in the midst of drought facilitated people's decision to migrate (Black et al., 2011). In Uganda, it was established that the decision to migrate as a climate change adaptation strategy was influenced by factors such as: age of household head; access to economic opportunities, such as credit; access to extension facilities; and security of land tenure (Hisali et al., 2011). From an economic perspective (see Figure 2 above), where individuals are not able to adapt to changes in their economic situation, especially to decline in production, there is the tendency to search for better economic opportunities. For example, Van Der Geest (2011) found that, in Ghana, there was an increase in out-migration as crop yield decreased. Therefore, it is certain that when the contextual factors combine with the risk of climate change, individuals are motivated to use migration as an adaptation strategy to both climate change and the contextual factors, especially the socio-economic factors.

\subsection{The Concept of Adaptation}

As already posited above, adaptation is not a new phenomenon but since the emergence of adaptation in the literature of climate change, various related definitions have been given to it. Many scholarly definitions of adaptation stem from that of the Intergovernmental Panel on Climate Change (IPCC). Adaptation refers to the adjustment in natural or human systems in response to actual or expected climatic stimuli or their effects, which moderates harm or exploits beneficial opportunities (IPCC, 2001). Adaptation may be undertaken at any level, from the individual or household level up to the level of state or international governance bodies (Smit \& Wandel, 2006). At each of these levels, adaptation can be in anticipation of an event or a reaction to an event that has already occurred (Nelson et al., 2007). In other words, adaptation involves taking action (reactive) or decision making (anticipatory) or both taking place sequentially (Jones \& Boyd, 2011): taking an adaptation decision and implementing the adaptation decision by migrating. This supports the explanation that adaptation relates to a decision-making process and the set of actions undertaken to maintain the capacity to deal with future perturbations to a system without the system undergoing significant changes in function and structural identity (Nelson et al., 2007).

From these explanations, the structure and function of a system may change depending on the set of opportunities that need to be exploited. In that regard, a system may not adapt to maintain its identity but improve on it. Similarly, where households and individuals have opportunities to decide on a range of adaptation strategies, they decide on those that will help improve their existing conditions. For emphasis, several studies, as demonstrated above, have identified migration as a climate change adaptation strategy used by households. For example, in Nepal, Jones and Boyd (2011) found that individuals, especially the energetic ones, use temporal

\footnotetext{
${ }^{1}$ The International Federation on Red Cross's (IFRC) Supplementary Guidance on the Policy on Migration refer to risks of migration as the range of issues that pose as threats to the physical health and integrity, mental wellbeing, and fundamental rights of migrants.
} 
migration as an adaptation strategy to food shortage, which is often caused by drought and unpredictable rain pattern. In Ghana, several studies have identified migration as a strategy to poor agro-ecological conditions, drought/dry-spell, and poor rain pattern of northern Ghana (see, for example, Van Der Geest, 2004; Van Der Geest, 2011), and the remote ${ }^{2}$ areas are often severely affected by climate change.

Linking climate change to remote areas, Maru and colleagues developed a two-based intriguing narrative. They posit that remote areas are resilient to climate change and are mostly the first to properly equip themselves towards adaptation; and secondly by virtue of their location, they are disadvantaged and remain the most vulnerable to climate change (Maru et al., 2014). The two statements are related in the sense that once the people are in remote areas, and not easily reached by so-called external interveners, they are compelled to develop their internal adaptive capacity to respond to climate change. But these arguments remain within the short term and are also dependent on the magnitude of climate change, that is, whether it is a slow onset or sudden onset. In fact, households do not resort to migration as a first adaptation strategy (Brown, 2006). Migration is the last resort and it happens when interventions do not come and community level adaptability is weakened. In other words, where vulnerability ${ }^{3}$ increases, then households will take a decision to migrate as a strategy.

\section{Study Area and Approach}

This research was conducted in the Nadowli-Kaleo District of Ghana. The District has a territorial size of $1,132.02 \mathrm{~km}^{2}$, which represents $6.1 \%$ of the land mass of the Upper West Region $\left(18,476 \mathrm{~km}^{2}\right)$. Although the district capital (Nadowli) is urbanising, the delineation of urban-rural shows that the District is entirely rural in nature and relies on agriculture as the main source of employment and livelihood, employing about $85 \%$ of the economically active population (Rademacher-Schulz \& Mahama, 2012). However, production is on subsistence basis and characterised by low output levels. It is estimated that the agricultural sector is growing at a rate of $2.1 \%$ which is far below the national target of $6 \%$ per annum (Ghana Statistical Service, 2014). In terms of demographic characteristics, the District has a population of 61,561 , comprising $47.7 \%$ males and $52.3 \%$ females. In terms of active population of the District, $66.9 \%$ of persons aged 15 and above is economically active. $92.9 \%$ of the active population is employed in private informal sector while $1.2 \%$ and $5.5 \%$ are employed in private formal and public (government) sectors respectively. Specifically, $69.9 \%$ of the population aged 15 years and above is engaged in agriculture, forestry and fishery. The proportion for males and females in these sectors are $79 \%$ and $62.5 \%$ respectively (Ghana Statistical Service, 2014).

\footnotetext{
${ }^{2}$ Remoteness is defined in terms of geography and access to essential services

${ }^{3}$ The degree to which a system is susceptible to, and unable to cope with, adverse effects of climate change, including climate variability and extremes (McLemme \& Hunter, 2010).
} 


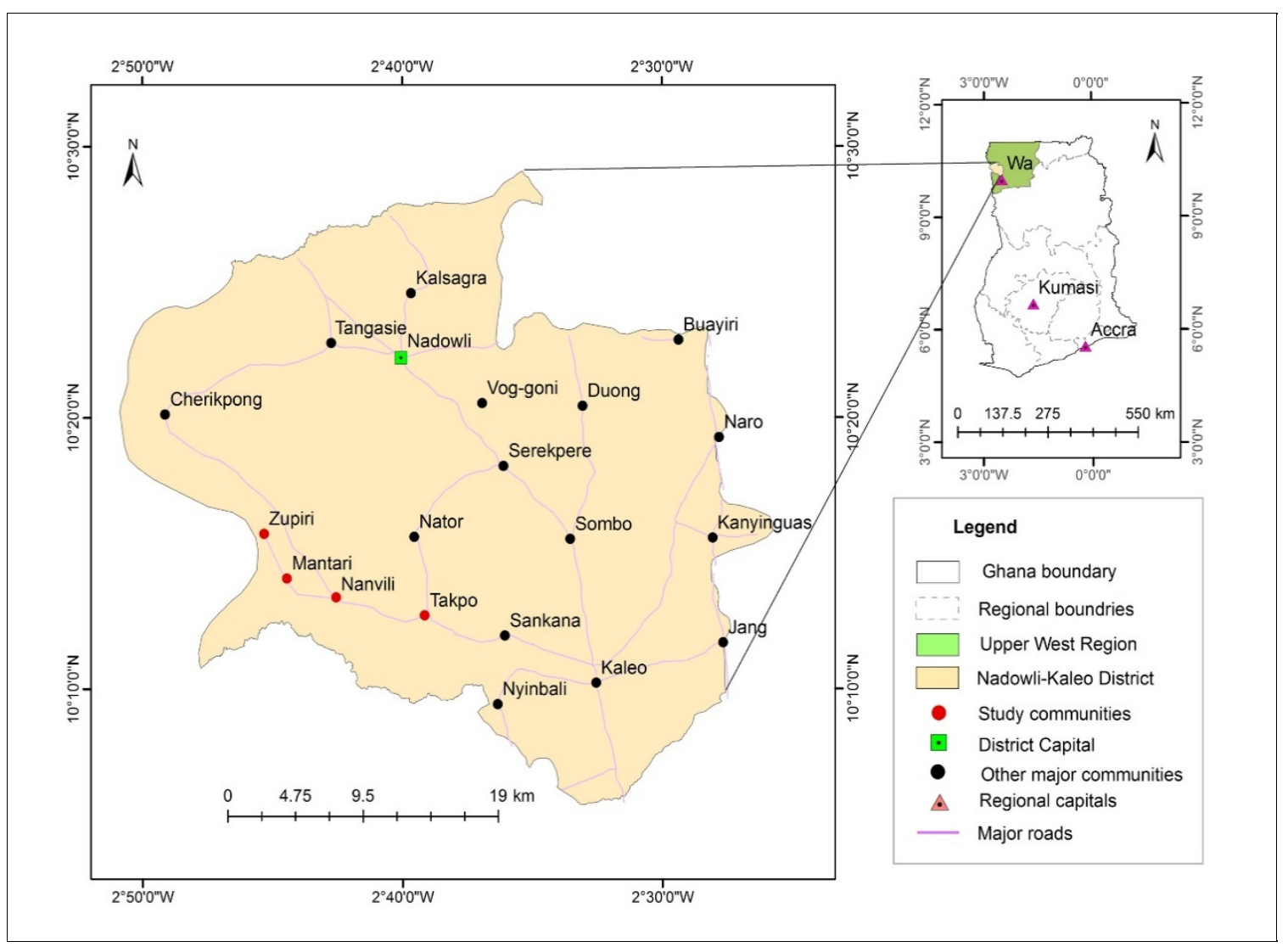

Figure 3. Map of the study area in district, regional and national context

Within the district, four communities: Takpo, Mantari, Nanville and Zupiri, were used for the study. These communities were selected because they relied heavily on rain-fed agriculture. More importantly, the selection was also based on the fact that CARE International was a partner to the United Nations University Institute for Environment and Human Security (UNU-EHS) in conducting the research and these were key communities in which CARE International worked (Rademacher-Schulz \& Mahama, 2012). It is also an area that is characterized by local and international migration because the district shares borders with Burkina Faso. The population distributions of the communities are presented in Table 1.

Table 1. Population structure and distribution of sample for the survey

\begin{tabular}{lcccc}
\hline \multicolumn{1}{c}{ Variables } & Takpo & Nanville & Mantari & Zupiri \\
\hline Total population & 1,700 & 921 & 174 & 176 \\
Male & 812 & 460 & 91 & 78 \\
Female & 888 & 461 & 83 & 98 \\
Number of houses & 207 & 191 & 21 & 9 \\
Number of households & 258 & 190 & 21 & 34 \\
\hline Sampled household & & & & \\
respondents & & & & \\
\hline Male & $71(79.8 \%)$ & $41(78.8 \%)$ & $6(66.7 \%)$ & $8(88.9 \%)$ \\
Female & $18(20.2 \%)$ & $11(21.2 \%)$ & $3(33.3 \%)$ & $1(11.1 \%)$ \\
Total & $89(100 \%)$ & $52(100 \%)$ & $9(100 \%)$ & $9(100 \%)$ \\
\hline
\end{tabular}

Source: Ghana Statistical Services, 2014 and Field survey, 2011 
This paper relied on data obtained from household survey we conducted for Care International and UNU-EHS. The total number of households surveyed was determined based on the experience of Care International in working with communities over the years which showed that households in the study area share similar features in terms of climate change and migration. Consequently, household questionnaires were administered randomly in 159 households (see Table 1). Due to the unstructured distribution of houses within the communities, simple random sampling was used to select the households for the questionnaire administration in all sections of the communities. The main data collected from households were the factors that households consider in deciding to migrate. The factors were categorised into social, economic and food security, and natural and environmental factors. These factors were categorised based on literature review on climate change and migration. The administered questionnaires were analysed using version 20 of the statistical package for social sciences. Out of the 159 households surveyed, 109 households, representing 68.6\%, had migration experience, thus limiting analysis to responses from those households with the migration experience. A Likert Scale, rating the factors as important, very important and not important, was used to measure household perception of the extent to which the factors influence their decision to migrate. A Likert Scale of three variables was used in this study because of the difficulty in translating variables that are above three from English to the local dialect.

\section{Results and discussion}

In this section, we analyse the results of the research. For a better appreciation of the analysis, we begin with a brief on the patterns of migration, and some key features of the migrants. This is followed by analysis of the factors that influenced migration decisions: these have been categorised into social factors, economic and food security related factors; and natural and environmental related factors.

\subsection{Migration Patterns}

The migration season was examined in order to get an overview of migration flows from the communities and to set the terrain to understand other related issues. The study established that migration takes place throughout the year. This is partly because some migrants often go to areas where small scale surface mining popularly called "galamsey" take place throughout the year. However, according to the respondents, the peak periods of migration are between July and August. Those who migrate to engage in farming often do so between May and June, and this period also coincides with scarcity of food at their places of origin. The major destinations are in southern Ghana and part of the middle belt of Ghana. Specifically, their favourite destinations are: (i) Tinga in the Northern Region (close to the middle belt of Ghana), where they go to engage in small scale surface mining; and (ii) Techiman in the Brong Ahafo Region (middle belt), where they go to work on crop farms as hired labourers. Other destinations include: (i) Obuasi and Konongo in the Ashanti Region, Prestea in the Western Region, and Kenyasi in the Brong Ahafo Region, where they go to engage in small scale surface mining; (ii) Atebubu in the Brong Ahafo Region, where they go to engage in farming; and (iii) Kejetia in the Ashanti Region, where mostly female migrants go to engage in food vending.

Generally, the migrants are the youth and they constitute $60 \%$ of the annual migrant population. The definition of youth in this study adopts Ghana's definition, where the youth policy defines "youth" as "persons who are within the age bracket of 15 and 35" (see Government of Ghana, 2010:5). The gender distribution shows that $60 \%$ of the migrants are men. These men do less varied jobs than their women counterparts. For instance, whilst the men mainly work in the mines and farms, the women, in addition to the mining and farm works, engage in catering services in food vending shops. The migrants mostly move individually, although there are cases of group movements. The group movements are based on existing friendship groups in the villages. As also noted by Massey et al. (1993), individuals make their own estimates of the costs and benefits of migration and act accordingly. Therefore, migration decisions are often made within the context of prevailing or expected social, economic and natural factors, which are elaborated in section 5.2.

\subsection{Factors That Influence Migration Decision}

The households' responses on factors that influence migration decisions were categorised into social, economic and food security, and natural and environmental factors.

\subsubsection{Social Factors}

Based on the household responses, social and personal factors, which influence migration decision relate to family relations, quality of life, education and health services delivery (see Table 2). While Jónsson (2010) viewed social factors as aspects of the concept of environment (natural and built), in climate change research, such a lumpy categorisation is similar to the argument that every factor is environmental. Such an argument distorts the identification of specific factors that shape migration decision. As such, we rather hold the view that 
social factors, for the purpose of migration and climate change, relate more to one's personality, attitudes, lifestyle and availability of social services, which are detailed in Table 2. On the other hand, natural and food security factors are more environmentally than socially-related.

Table 2. Social factors that influence migration decision

\begin{tabular}{|c|c|c|c|c|c|c|c|c|}
\hline \multirow{3}{*}{ Social factors } & \multicolumn{6}{|c|}{ Rating } & \multirow{2}{*}{\multicolumn{2}{|c|}{$\begin{array}{c}\text { Total } \\
\text { respondents }\end{array}$}} \\
\hline & \multicolumn{2}{|c|}{$\begin{array}{c}\text { Very } \\
\text { Important }\end{array}$} & \multicolumn{2}{|c|}{ Important } & \multicolumn{2}{|c|}{$\begin{array}{c}\text { Not } \\
\text { Important }\end{array}$} & & \\
\hline & No. & $\%$ & No. & $\%$ & No. & $\%$ & No. & $\%$ \\
\hline No school for my children in the village & 8 & 7.3 & 18 & 16.5 & 83 & 76.2 & 109 & 100 \\
\hline Insufficient health care services in the village & 7 & 6.4 & 22 & 20.2 & 80 & 73.5 & 109 & 100 \\
\hline No relatives and friends in the village & 2 & 1.8 & 20 & 18.3 & 87 & 79.8 & 109 & 100 \\
\hline $\begin{array}{l}\text { Family-related reasons, such as death of } \\
\text { parent }\end{array}$ & 4 & 3.7 & 24 & 22.0 & 81 & 74.3 & 109 & 100 \\
\hline Social life of the city as source of attraction & 5 & 4.6 & 26 & 23.9 & 78 & 71.5 & 109 & 100 \\
\hline My friends already live in the city & 3 & 2.8 & 21 & 19.2 & 85 & 78.0 & 109 & 100 \\
\hline The quality of living in the city is better & 1 & 0.9 & 28 & 25.7 & 80 & 73.4 & 109 & 100 \\
\hline Desire to build up one's own life in the city & 3 & 2.8 & 18 & 16.5 & 88 & 80.7 & 109 & 100 \\
\hline $\begin{array}{l}\text { Desire to become independent from one's } \\
\text { family }\end{array}$ & 1 & 0.9 & 26 & 23.9 & 82 & 75.2 & 109 & 100 \\
\hline Conflict over natural resources & 4 & 3.7 & 17 & 15.6 & 88 & 80.7 & 109 & 100 \\
\hline Average & & 3.5 & & 20.2 & & 76.3 & & \\
\hline
\end{tabular}

As shown in Table 2, an average of $76.3 \%$ of the respondents indicated that social factors were not important in influencing migration decisions. This is similar to the case in Bangladesh where Ishtiaque and Ullah (2013) established that social factors, except occupation at origin, do not pose as significant influence in migration decisions. This implies that decisions to migrate in the midst of climate change are not strongly influenced by social factors. Although social factors, including the existence of social networks at the destination, can influence the decision to migrate (Jónsson, 2010), they are not strong influential factors as established in this study. Hence, social factors are secondary in deciding to migrate or not. Nonetheless, the household composition influences migration structure. For instance, the study established that where there are three or more youth in a household, they migrate in turns, such that whilst some members migrate to earn income to support the house, others stay back to take care of the aged and general household upkeep. Whereas social factors are relevant, as indicated in the empirical literature, in shaping migration, they are not directly affected by climate change. However, economic and food security factors tend to be severely affected by climate change (Black et al., 2011; Gregory et al., 2005; see, for example, Van Der Geest, 2011) and serve primarily as the basis of migration in remote areas.

\subsubsection{Economic and Food Security Related Factors}

There is a chain of relationship between climate change, economic conditions and migration. That is, while economic conditions are affected by climate change, the state of these conditions in turn influences decision to migrate. Table 3 shows the economic and food security related factors that influence households' decision to migrate. 
Table 3. Economic and food security related factors affecting migration decision

\begin{tabular}{|c|c|c|c|c|c|c|c|c|}
\hline \multirow{4}{*}{ Factors } & \multicolumn{6}{|c|}{ Rating } & \multirow{3}{*}{\multicolumn{2}{|c|}{ Total }} \\
\hline & \multirow{2}{*}{\multicolumn{2}{|c|}{$\begin{array}{c}\text { Very } \\
\text { Important }\end{array}$}} & \multirow{2}{*}{\multicolumn{2}{|c|}{ Important }} & \multirow{2}{*}{\multicolumn{2}{|c|}{$\begin{array}{c}\text { Not } \\
\text { Important }\end{array}$}} & & \\
\hline & & & & & & & & \\
\hline & No. & $\%$ & No. & $\%$ & No. & $\%$ & No. & $\%$ \\
\hline No enough income & 45 & 41.3 & 58 & 53.2 & 6 & 5.5 & 109 & 100 \\
\hline Limited job opportunities at the origin & 42 & 38.5 & 58 & 53.2 & 9 & 8.3 & 109 & 100 \\
\hline Better job opportunities in the city & 15 & 13.8 & 47 & 43.1 & 47 & 43.1 & 109 & 100 \\
\hline No land available for farming & 13 & 11.9 & 27 & 24.8 & 69 & 63.3 & 109 & 100 \\
\hline Work related to my skills is not available & 4 & 3.7 & 26 & 23.8 & 79 & 72.5 & 109 & 100 \\
\hline Decline in crop production & 67 & 61.5 & 36 & 33 & 6 & 5.5 & 109 & 100 \\
\hline Decline in animal production & 44 & 40.4 & 32 & 29.4 & 33 & 30.2 & 109 & 100 \\
\hline Increasing food prices in the market & 27 & 24.8 & 55 & 50.5 & 27 & 24.7 & 109 & 100 \\
\hline $\begin{array}{l}\text { Decline in fish production (due to shallow } \\
\text { rivers/canals) }\end{array}$ & - & - & 3 & 2.8 & 106 & 97.2 & 109 & 100 \\
\hline Average & & $29.5 \%$ & & $34.9 \%$ & & $38.9 \%$ & & \\
\hline
\end{tabular}

From Table 3, it is evident that economic and food security related factors are key drivers in a household's decision to migrate: averagely, $34.9 \%$ and $29.5 \%$ indicated that these factors are important and very important respectively in deciding to migrate. The dominant decision drivers are decline in crop and animal production, inadequate income, and unemployment. Although economic-related factors include access to land and skill-career match, these are not rated by households as important factors in deciding to migrate. This is because access to land for farming is not a major concern, neither do the skills required for their economic activities (peasant farming) present key challenges. Although the communities are close to the Black Volta River, decline in fish production is not an important influential factor in deciding to migrate. This is because fishing is not a major economic activity. However, this does not mean that the level of fish production has not declined.

According to the respondents, the land is not fertile for crop production and, as a response, they migrate in search of fertile land. Since levels of production directly influence level of income of these communities, low production would reduce the income levels, thus, compelling individuals to migrate. Impliedly, there is a link between climate change and food security, as established by some authors (Gregory et al., 2005). Certainly, a decline in production levels amidst increase in demand will lead to increase in prices of products. Thus, inadequate income coupled with increasing prices of products in the market will facilitate a household's decision to migrate. Interestingly, $43.1 \%$ of respondents did not rate limited job opportunities as important in deciding to migrate. This is because the migrants do not often go to cities because the activities they engage in (farming and small scale mining) are rural based. While prospects of job at the destination is important (see Parkins, 2010), the destination in this instance is not city centres. In addition to the social and economic factors that influence migration decision, there are natural related factors that influence household's decision to migrate.

\subsubsection{Natural and Environmental Related Factors}

According to the respondents, natural and environmental factors which influence their decision to migrate include soil degradation, water shortage, drought, unreliable harvest, changing rainfall pattern and flood, as shown in Table 4. 
Table 4. Natural and environmental factors that affect migration decision

\begin{tabular}{|c|c|c|c|c|c|c|c|c|}
\hline \multirow{3}{*}{ Natural Factors } & \multicolumn{6}{|c|}{ Rating } & \multicolumn{2}{|c|}{ Total } \\
\hline & \multicolumn{2}{|c|}{$\begin{array}{c}\text { Very } \\
\text { Important }\end{array}$} & \multicolumn{2}{|c|}{ Important } & \multicolumn{2}{|c|}{$\begin{array}{c}\text { Not } \\
\text { Important } \\
\end{array}$} & & \\
\hline & No. & $\%$ & No. & $\%$ & No. & $\%$ & No. & $\%$ \\
\hline Soil degradation & 25 & 23 & 60 & 55.0 & 24 & 22.0 & 109 & 100 \\
\hline Potable water shortage & 10 & 9.2 & 41 & 37.6 & 58 & 53.2 & 109 & 100 \\
\hline Drought & 28 & 25.7 & 67 & 61.5 & 14 & 12.8 & 109 & 100 \\
\hline Unreliable harvest & 38 & 34.9 & 48 & 44.0 & 23 & 21.1 & 109 & 100 \\
\hline Shifting seasonal rainfalls & 49 & 45.0 & 49 & 45.0 & 11 & 10.0 & 109 & 100 \\
\hline $\begin{array}{l}\text { Heavy rainfall events, leading to crop } \\
\text { destruction }^{4}\end{array}$ & 20 & 18.3 & 45 & 41.3 & 44 & 40.4 & 109 & 100 \\
\hline Insect plagues & 6 & 5.5 & 44 & 40.4 & 59 & 54.1 & 109 & 100 \\
\hline Flood $^{5}$ & 4 & 3.7 & 68 & 62.4 & 37 & 33.9 & 109 & 100 \\
\hline Average & & 21.1 & & 49.5 & & 29.4 & & \\
\hline
\end{tabular}

As shown in Table 4, natural and environmental-related factors play a significant role in household's decision to migrate. On average, at least $49.5 \%$ of the respondents rated natural factors as important in deciding to use migration as an adaptation strategy. Specifically, $45.0 \%$ of the respondents rated shifting seasonal rainfalls as very important, and important in influencing migration decisions. Other key elements that trigger migration decisions are poor soils, droughts and floods. The natural and environmental factors have an impact on economic activities of households. This partly explains the significance of these categories of factors in a household's decision to migrate. In relating migration continuum to influential factors, Laczko and Aghazarm (2009) posit that households are forced to migrate in situations such as natural disasters and that they voluntarily migrate in situations of gradual environmental change. On the other hand, this paper argues that even in situations of gradual climate change effects, households migrate in order to meet immediate needs, and eventually cope with the effects, especially if they have limited adaptive capacity at the place of origin. Although in these communities households have not suffered major natural catastrophes, as suggested by Laczko and Aghazarm (2009), the gradual insurgence of climate change and its related impact have compelled household members to migrate. This reduces the relevance of voluntary migration in the midst of climate change.

\section{Conclusion}

Rural communities continue to rely on rain fed agriculture as the main source of livelihood which is vulnerable to climate change. Fundamentally, climate change impacts on the economic, natural and social aspects of human living. In response to the impact of climate change, several strategies are often explored, and migration is one of such strategies used by rural folks. Therefore, with the impact of climate change on rain fed rural livelihood amidst limited adaptation strategies that will allow rural folk to remain in their places of origin, migration becomes the main choice in such areas. Within the broad social, economic and natural factors that drive migration, this study showed that whilst social factors were not important in migration decision of households, economic and natural factors were important influencing factors. Based on the specific sub-drivers that shape the decision of households to use migration as an adaptation strategy, a relationship between the economic and environmental factors could be inferred: shifting rainfalls, degrading soils, drought and floods contribute to the decline in crop and animal production, resulting in lower incomes of households. Our study shows that the debate on climate change and migration should no longer be whether climate change causes human migration or not but how the impact of climate change influences migration choices and what households consider before embarking on migration as an adaptation strategy.

As demonstrated in this paper, the decisions to migrate were taken in response to a particular set of stimuli that come with climate change. In mapping adaptation (anticipatory and/or reactive) to migration (voluntary or

\footnotetext{
${ }^{4}$ This is a situation where the crops do not require heavy rains and, in such cases, any heavy rains lead to crop destruction.

${ }^{5}$ Flood cause destruction of crops and other properties
} 
forced), it remains unclear the position of adaptation within the continuum of migration. This is because judging the migratory behaviour of climate change affected persons or community as "voluntary" is problematic. Within the wider theory of attribution, tagging migration to the extremes, especially the voluntary end of the cord, is difficult to define. That is, actions are often attributed to an event, implying that without the event, the action may not take place. In that case, rather than working with perceived voluntarism in migratory discourse, researchers and the policy community should rather focus on what we will term as "resolutionary migration". This is because voluntary migration tends to ignore the actual control of the migrant over the situation (climate change related events). But "resolutionary" migration discourse, as argued in this paper, seeks to understand the individual adaptability (based on the slow-onset of climate change), the contextual factors surrounding the individual and finally how he/she "resolved" to migrate as the best option. This kind of analysis allows the policy community to devise practical adaptive capacity building measures that are community specific.

\section{Acknowledgement}

The authors would like to acknowledge that this paper was produced from data obtained in a larger study (Where the Rainfalls) conducted by CARE International and the United Nations University Institute for Environment and Human Security (UNU-EHS) Bonn in the Nadowli District of Ghana. We thus acknowledge, and are grateful to CARE International, UNU-EHS, the AXA Group and John D. and Catherine T. MacAthur Foundation who financially supported the research. We are also grateful to the Research Team.

\section{References}

Adger, W. N., Kelly, P. M., Winkels, A., Huy, L. Q., \& Locke, C. (2002). Migration, remittances, livelihood trajectories, and social resilience. AMBIO: A Journal of the Human Environment, 31(4), 358-366. https://doi.org/10.1579/0044-7447-31.4.358

Barnett, J. R., \& Webber, M. (2010). Accommodating migration to promote adaptation to climate change. World Bank Policy Research Working Paper Series. https://doi.org/10.1596/1813-9450-5164

Black, R., Bennett, S. R., Thomas, S. M., \& Beddington, J. R. (2011). Climate change: Migration as adaptation. Nature, 478(7370), 447-449. https://doi.org/10.1038/478477a

Brown, O. (2008). Migration and climate change. IOM migration research series no. 31. International Organization for Migration, Geneva.

Brugger, J., \& Crimmins, M. (2013). The art of adaptation: Living with climate change in the rural American $\begin{array}{llll}\text { Southwest. Global } & \text { Environmental }\end{array}$ https://doi.org/10.1016/j.gloenvcha.2013.07.012

Conway, D., \& Schipper, E. L. F. (2011). Adaptation to climate change in Africa: Challenges and opportunities identified from Ethiopia. Global Environmental Change, 21(1), 227-237. https://doi.org/10.1016/j.gloenvcha.2010.07.013

Deressa, T. T., Hassan, R. M., Ringler, C., Alemu, T., \& Yesuf, M. (2009). Determinants of farmers' choice of adaptation methods to climate change in the Nile Basin of Ethiopia. Global Environmental Change, 19(2), 248-255. https://doi.org/10.1016/j.gloenvcha.2009.01.002

Ghana Statistical Service. (2014). 2010 Population and housing census. District analytical report Nadowli-Kaleo District. Accra.

Government of Ghana. (2010). National Youth Policy of Ghana. Accra: Ministry of Youth and Sports.

Gregory, P. J., Ingram, J. S., \& Brklacich, M. (2005). Climate change and food security. Philosophical Transactions of the Royal Society B: Biological Sciences, 360(1463), 2139-2148. https://doi.org/10.1098/rstb.2005.1745

Hisali, E., Birungi, P., \& Buyinza, F. (2011). Adaptation to climate change in Uganda: evidence from micro level data. Global Environmental Change, 21(4), 1245-1261. https://doi.org/10.1016/j.gloenvcha.2011.07.005

Hugo, G. (1996). Environmental concerns and international migration. International migration review, 105-131. https://doi.org/10.2307/2547462

Hunter, L. M. (2005). Migration and environmental hazards. Population and environment, 26(4), 273-302. https://doi.org/10.1007/s11111-005-3343-x

IPCC. (2001). Climate Change 2001: Impacts, Adaptation and Vulnerability. Contribution of Working Group II to the Third Assessment Report of the Intergovernmental Panel on Climate Change. Cambridge, UK. 
Ishtiaque, A., \& Ullah, M. S. (2013). The influence of factors of migration on the migration status of rural-urban migrants in Dhaka, Bangladesh. Journal of Studies and Research in Human Geography, 7(2), 45-52. https://doi.org/10.5719/hgeo.2013.72.45

Jones, L., \& Boyd, E. (2011). Exploring social barriers to adaptation: insights from Western Nepal. Global Environmental Change, 21(4), 1262-1274. https://doi.org/10.1016/j.gloenvcha.2011.06.002

Jónsson, G. (2010). The environmental factor in migration dynamics: a review of African case studies.

Kahn, M. E. (2003). Two measures of progress in adapting to climate change. Global Environmental Change, 13(4), 307-312. https://doi.org/10.1016/S0959-3780(03)00052-9

Kwankye, S., Anarfi, J., Tagoe, C., \& Castaldo, A. (2009). Independent North-South child migration in Ghana: The decision making process. Development Research Centre on Migration, Globalisation and Poverty, University of Sussex Working Paper T-29.

Laczko, F., \& Aghazarm, C. (2009). Migration, environment and climate change: Assessing the evidence: International Organization for Migration Geneva.

Lilleør, H. B., \& Van den Broeck, K. (2011). Economic drivers of migration and climate change in LDCs. Global Environmental Change, 21, S70-S81. https://doi.org/10.1016/j.gloenvcha.2011.09.002

Maru, Y. T., Smith, M. S., Sparrow, A., Pinho, P. F., \& Dube, O. P. (2014). A linked vulnerability and resilience framework for adaptation pathways in remote disadvantaged communities. Global Environmental Change, 28, 337-350. https://doi.org/10.1016/j.gloenvcha.2013.12.007

Massey, D. S., Arango, J., Hugo, G., Kouaouci, A., Pellegrino, A., \& Taylor, J. E. (1993). Theories of international migration: a review and appraisal. Population and development review, 431-466. https://doi.org/10.2307/2938462

McLeman, R. (2011). Climate change, migration and critical international security considerations. International Organization for Migration (IOM).

McLeman, R. A., \& Hunter, L. M. (2010). Migration in the context of vulnerability and adaptation to climate change: insights from analogues. Wiley Interdisciplinary Reviews: Climate Change, 1(3), 450-461. https://doi.org/10.1002/wcc.51

Meier, P., Bond, D., \& Bond, J. (2007). Environmental influences on pastoral conflict in the Horn of Africa. Political Geography, 26(6), 716-735. https://doi.org/10.1016/j.polgeo.2007.06.001

Morton, A., Boncour, P., \& Laczko, F. (2008). Human security policy challenges. Forced Migration Review, 31(5), 05-07.

Mortreux, C., \& Barnett, J. (2009). Climate change, migration and adaptation in Funafuti, Tuvalu. Global Environmental Change, 19(1), 105-112. https://doi.org/10.1016/j.gloenvcha.2008.09.006

Nelson, D. R., Adger, W. N., \& Brown, K. (2007). Adaptation to environmental change: contributions of a resilience framework. Annual Review of Environment and Resources, 32(1), 395. https://doi.org/10.1146/annurev.energy.32.051807.090348

Parkins, N. (2010). Push and pull factors of migration. American Review of Political Economy, 8(2), 6-24.

Rademacher-Schulz, C., \& Mahama, E. S. (2012). Where the Rain Falls Project - Case Study: Ghana. Results from Nadowli District, Upper West Region. (Report No. 3). Bonn, United Nations University. Institute for Environment and Human Security (UNU-EHS):

Renaud, F. G., Dun, O., Warner, K., \& Bogardi, J. (2011). A decision framework for environmentally induced migration. International Migration, 49(s1), e5-e29. https://doi.org/10.1111/j.1468-2435.2010.00678.x

Sherbinin, A. D., Castro, M., \& Gemenne, F. (2010). Preparing for Population Displacement and Resettlement Associated with Large Climate Change Adaptation and Mitigation Projects, Background Paper for the Bellagio Workshop. Retrieved from http://www.iddri.org/Activites/Ateliers/101103_bellagio workshopbackground paper.pdf

Smit, B., \& Wandel, J. (2006). Adaptation, adaptive capacity and vulnerability. Global Environmental Change, 16(3), 282-292. https://doi.org/10.1016/j.gloenvcha.2006.03.008

Smith, P. J. (2007). Climate Change, Mass Migration and the Military Response, Foreign Policy Research Institute. 
Todaro, M. P., \& Smith, S. C. (2009). Economic Development (10th ed.). England: Pearson Education Limited.

Van Der Geest, K. (2004). We're managing!": climate change and livelihood vulnerability in Northwest Ghana: Leiden: African Studies Centre.

Van Der Geest, K. (2011). North South migration in Ghana: what role for the environment? International Migration, 49(s1), e69-e94. https://doi.org/10.1111/j.1468-2435.2010.00645.x

Wise, R., Fazey, I., Smith, M. S., Park, S., Eakin, H., Van Garderen, E. A., \& Campbell, B. (2014). Reconceptualising adaptation to climate change as part of pathways of change and response. Global Environmental Change, 28, 325-336. https://doi.org/10.1016/j.gloenvcha.2013.12.002

\section{Copyrights}

Copyright for this article is retained by the author(s), with first publication rights granted to the journal.

This is an open-access article distributed under the terms and conditions of the Creative Commons Attribution license (http://creativecommons.org/licenses/by/4.0/). 